\title{
Erratum to: Estimating the maximum impact force of dry granular flow based on pileup characteristics
}

XIAO Si-you ${ }^{1,2 \#}$ iDhttps://orcid.org/oooo-0oo2-6451-1964; e-mail: xsyo7@imde.ac.cn

SU Li-jun1,2,3\# (Dhttps://orcid.org/oooo-ooo1-9972-4698; e-mail: sulijun1976@163.com

JIANG Yuan-jun 1,2* i https://orcid.org/oooo-0oo1-5922-8382; e-mail: yuanjun.jiang.civil@gmail.com

MEHTAB Alam 1,2 (D https://orcid.org/oooo-0003-2099-7103; e-mail: engr_mehtab@yahoo.com

LI Cheng1,2,3 Đhttps://orcid.org/oooo-ooo2-1096-6621; e-mail: 292320163@qq.com

LIU Dao-chuan",2,4 i https://orcid.org/oooo-0oo2-7344-1902; e-mail: daochuanliu@imde.ac.cn

*Corresponding author

\#Co-first author

1 Key Laboratory of Mountain Hazards and Earth Surface Processes, and Institute of Mountain Hazards and Environment, Chinese Academy of Sciences, Chengdu 610041, China

2 University of Chinese Academy of Sciences, Beijing 100049, China

3 CAS Center for Excellence in Tibetan Plateau Earth Sciences, Beijing 100101, China

4 Sichuan Highway Planning, Design, Research Institute Ltd, Chengdu 610041, China

Citation: Xiao SY, Su LJ, Jiang YJ, et al. (2022) Erratum to: Estimating the maximum impact force of dry granular flow based on pileup characteristics. Journal of Mountain Science 19(7). https://doi.org/10.1007/s11629-019-5615-4

Erratum to: J. Mt. Sci. (2019) 16(10): 2435-2452

https://doi.org/10.1007/s11629-019-5428-5

The Acknowledgements chapter is missing in the original article. The Acknowledgements chapter should be as follows.

Acknowledgements

The authors give sincere acknowledgement to Strategic Priority Research Program of Chinese Academy of Sciences (XDA 20030301) and the National Natural Science Foundation of China (Grant No. 41761144077) for the completion of this research. The research presented in this paper was also jointly supported by the CAS Pioneer Hundred Talents Program and the National Natural Science Foundation of China (Grant No. 41502334).

The online version of the original article can be found at https://doi.org/10.1007/s11629-019-5428-5. 